ISSN 0258-7122

Bangladesh J. Agril. Res. 34(1) : 105-111, March 2009

\title{
PERFORMANCES OF FRENCH BEAN AS INFLUENCED BY PLANT DENSITY AND NITROGEN APPLICATION
}

\author{
M. MONirUZZAMAN ${ }^{1}$, G. M. A. HALim² AND Z. A. FirOZ ${ }^{3}$
}

\begin{abstract}
Field experiments with French bean comprising two varieties (BARI bush bean1 and BARI bush bean-2), three plant densities (500 x 10 $30^{3}, 333 \times 10^{3}$, and $250 \mathrm{x}$ $10^{3}$ plants/ha as maintained by $20 \times 10,30 \times 10$, and $40 \times 10 \mathrm{~cm}$ spacings, respectively) and three levels of $\mathrm{N}(0,60$, and $120 \mathrm{~kg} / \mathrm{ha})$ were conducted at the Agricultural Research Station, Raikhali in the district of Rangamati during the winter (rabi) seasons of 2004-05 and 2005-06. BARI bush bean-1 outyielded BARI bush bean-2. The lowest plant density ( 250 x 10 plants/ha) recorded significantly higher values of growth and yield attributes, except plant height which was the maximum with the highest plant density of $500 \times 10^{3}$ plants/ha. The highest plant density of $\left(500 \times 10^{3}\right.$ plants/ha) resulted in the highest pod yield in comparison with the lower and medium plant densities. Application of $120 \mathrm{~kg} \mathrm{~N} / \mathrm{ha}$ coupled with the highest plant density ( $500 \times 10^{3}$ plants/ha) gave the maximum pod yield of 34.3 t/ha and 30.2 t/ha in BARI bush bean-I and BARI bush bean-2, respectively.
\end{abstract}

Key Words: French bean, plant density, nitrogen.

\section{Introduction}

French bean (Phaseolus vulgaris L.) is an important legume vegetable grown during rabi season for its tender green pods with high protein, calcium and iron contents. The Bangladesh Agricultural Research Institute (BARE) has developed two potential French bean varieties. Plant density and soil fertility are the two important factors of crop production. Several authors have reported that pod yield of French bean increases with the increase of plant density (Ali 1989: Dhanjal et al., 2001; Mozumder et al., 2003; Shivakumar et al., 1996; Singh et al., 1996). Mozumder et al. (2003) obtained the highest yield of French bean from the plants spaced at $25 \mathrm{~cm}$ x $10 \mathrm{~cm}$, while Dhanjal et al. (2001) and Shivakumar et al. (1996) in their experiments observed the highest yield at the spacing of $30 \mathrm{~cm} \mathrm{x}$ $10 \mathrm{~cm}$ and $30 \times 15 \mathrm{~cm}$, respectively. Contrary to the general recommendation of reduced nitrogen application to legume crops because of their ability to fix atmospheric nitrogen, French bean readily responds to large dose of nitrogen. French bean possesses high yield potential, but unlike other leguminous crops, it does not nodulate with the native rhizobia and its response to applied nitrogen is

\footnotetext{
${ }^{1}$ Senior Scientific Officer (Horticulture), Agricultural Research Station, Raikhali, Chandraghona, Rangamati Hill District-4531, ${ }^{2}$ Senior Scientific Officer, Vegetable Section, HRC, BARI, ${ }^{3}$ Senior Scientific Officer (Horticulture), Regional Agricultural Research Station, Hathazari, Chittagong, Bangladesh.
} 
as high as $120 \mathrm{~kg} / \mathrm{ha}$ (Srinivas and Naik, 1990 and Rana et al., 1998). Practically, a suitable combination of plant spacing and nitrogen level is very important in producing higher yield of French bean. Thus, the present investigation was undertaken to determine proper spacing and optimum nitrogen dose for realizing the maximum yield potential of French bean in south-eastern hilly region.

\section{Materials and Method}

The experiment was conducted at the Agricultural Research Station (ARS), Raikhali, Rangamati Hill district during the winter (rabi) seasons of 2004-05 and 2005-06. The soil was sandy clay loam with $\mathrm{pH} 5.6$, and contained $0.53 \%$ organic carbon, $0.92 \%$ organic matter, $0.079 \%$ total $\mathrm{N}, 8.0 \mu \mathrm{g} / \mathrm{g}$ available phosphorus and $0.17 \mathrm{meq} / 100 \mathrm{~g}$ soil exchangeable potassium. The treatments comprising two varieties (BARI bush bean-1 and BARI bush bean-2), three plant densities $\left(500 \times 10^{3}, 333 \times 10^{3}\right.$, and $250 \times 10^{3}$ plants/ha) and three levels of nitrogen $(0,60$, and $120 \mathrm{~kg} / \mathrm{ha})$ were replicated thrice in $2 \times 3 \times 3$ RCBD factorial design. The size of each plot was $3.0 \times 1.2 \mathrm{~m}$. Plant densities of $500 \times 10^{3}, 333 \times$ $10^{3}$ and $250 \times 10^{3}$ plants/ha were maintained by adopting $20 \times 10,30 \times 10$, and $40 \times 10 \mathrm{~cm}$ spacings, respectively. Seeds were sown on 11 November 2004 and 20 November 2005 at the rate of two seeds/hill. After 15 days of sowing (DAS) thinning was done keeping one healthy seedling/hill. A uniform dose of P (35 $\mathrm{kg} / \mathrm{ha}), \mathrm{K}(66 \mathrm{~kg} / \mathrm{ha}$ ), and cowdung (5 t/ha) was used in this experiment. The full dose of phosphorous, potassium, and cowdung, and half of nitrogen as per treatment was applied during planting and the rest half of nitrogen was applied 25 days after sowing. The source of N, P, and K were urea, TSP, and MOP. In addition to pre-sowing irrigation, four additional irrigations were given to the crop. Tender green pods were picked out at regular intervals for recording plotwise yield and a total of five pickings was made.

The data on plant height, number of branches per plant, number of plants $/ \mathrm{m}^{2}$, pod length, pod width, number of green pods per plant and green pod weight per plant and green pod weight per plot were recorded from randomly selected 10 plants of the inner rows. The plot yield was converted to per hectare yield. The different parameters were analyzed statistically and the treatment means were separated by DMRT at 5\% level of probability.

\section{Results and Discussion}

\section{Varietal performances}

The data on the effect of varieties, plant density, and nitrogen levels on the yield attributers and pod yield have been presented in Table 1. There was no significant difference in two varieties (BARI bush bean-I and BAR! bush bean-2) with respect to branches per plant, pod length, and number of green pods per 
plant. However, the plant height, pod width, and green pod weight per plant were significantly higher in BARI bush bean-I as compared to BARI bush bean-2. BARI bush bean-I gave significantly higher yield than BARI bush bean-2.

Table 1. Effect of variety, plant density, and nitrogen on the yield attributes and yield of French bean (average of 2 years).

\begin{tabular}{l|c|c|c|c|c|c|c}
\hline \multicolumn{1}{c|}{ Treatments } & $\begin{array}{c}\text { Plant } \\
\text { height } \\
(\mathrm{cm})\end{array}$ & $\begin{array}{c}\text { No. of } \\
\text { branches } \\
\text { /plant }\end{array}$ & $\begin{array}{c}\text { Pod } \\
\text { length } \\
(\mathrm{cm})\end{array}$ & $\begin{array}{c}\text { Pod } \\
\text { width } \\
(\mathrm{cm})\end{array}$ & $\begin{array}{c}\text { No. of } \\
\text { green } \\
\text { fruits } \\
\text { /plant }\end{array}$ & $\begin{array}{c}\text { Green } \\
\text { pod } \\
\text { wt/plant }\end{array}$ & $\begin{array}{c}\text { Green } \\
\text { pod yield } \\
\text { (t/ha })\end{array}$ \\
\hline Variety & & & & & & & \\
$\mathrm{V}_{1}$ & $45.3 \mathrm{a}$ & 4.02 & 12.3 & $0.73 \mathrm{a}$ & 20.5 & $80.5 \mathrm{a}$ & $23.3 \mathrm{a}$ \\
$\mathrm{V}_{2}$ & $41.8 \mathrm{~b}$ & 4.37 & 12.2 & $0.66 \mathrm{~b}$ & 20.1 & $71.4 \mathrm{~b}$ & $21.4 \mathrm{~b}$ \\
Plant density & & & & & & & \\
$\mathrm{S}_{1}$ & $44.5 \mathrm{a}$ & $3.86 \mathrm{~b}$ & $11.6 \mathrm{~b}$ & $0.60 \mathrm{~b}$ & $17,8 \mathrm{~b}$ & $58.8 \mathrm{c}$ & $24.5 \mathrm{a}$ \\
$\mathrm{S}_{2}$ & $43 . \mathrm{b}$ & $4.28 \mathrm{a}$ & $12.3 \mathrm{a}$ & $0.70 \mathrm{a}$ & $19.8 \mathrm{~b}$ & $77.5 \mathrm{~b}$ & $22.6 \mathrm{~b}$ \\
$\mathrm{~S}_{3}$ & $43.0 \mathrm{~b}$ & $4.44 \mathrm{a}$ & $12.7 \mathrm{a}$ & $0.71 \mathrm{a}$ & $26.3 \mathrm{a}$ & $87.3 \mathrm{a}$ & $20.0 \mathrm{c}$ \\
$\mathrm{Nitrogen} \mathrm{rate}$ & & & & & & & \\
$\mathrm{N}_{0}$ & $39.8 \mathrm{c}$ & $3.85 \mathrm{c}$ & $\mathrm{I} 1.9 \mathrm{~b}$ & $0.66 \mathrm{~b}$ & $15.6 \mathrm{c}$ & $54.6 \mathrm{c}$ & $15.9 \mathrm{c}$ \\
$\mathrm{N}_{1}$ & $44.0 \mathrm{~b}$ & $4.19 \mathrm{~b}$ & $12.4 \mathrm{a}$ & $0.69 \mathrm{~b}$ & $21.5 \mathrm{~b}$ & $21.5 \mathrm{~b}$ & $23.3 \mathrm{~b}$ \\
$\mathrm{~N}_{2}$ & $46.7 \mathrm{a}$ & $4.54 \mathrm{a}$ & $12.4 \mathrm{a}$ & $0.72 \mathrm{a}$ & $23.8 \mathrm{a}$ & $23.8 \mathrm{a}$ & $27.8 \mathrm{a}$ \\
\hline $\mathrm{CV}(\%)$ & 3.48 & 6.58 & 4.90 & 2.86 & 5.01 & 5.01 & 5.81
\end{tabular}

Figures having uncommon letters in a column are significantly different at $5 \%$ level of probability by

DMRT

$\mathrm{S}_{1}=500 \times 10^{3}, \mathrm{~S}_{2}=333 \times 10^{3}, \mathrm{~S}_{3}=250 \times 10^{3}$ plants $/$ ha

$\mathrm{N}_{0}=0, \mathrm{~N}_{1}=60$, and $\mathrm{N}_{2}=120 \mathrm{~kg} \mathrm{~N} / \mathrm{ha} ; \mathrm{V}_{1}=$ BARI Bush bean- $1, \mathrm{~V}_{2}=$ BARI Bush bean-2

\section{Effects of plant density}

Plant height increases with the increase of plant density because of competition of light (Dhanjal et al., 2001). Maximum plant height $(44.5 \mathrm{~cm})$ was obtained from the highest plant density ( $500 \times 10^{3}$ plants/ha) and the lowest from the lowest plant density ( $250 \times 10^{3}$ plants/ha). Yield components viz., branches per plant, pod length, pod width, number of green pods per plant and green pod weight per plant recorded the highest values at lower plant density. However, it was not reflected in pod yield per ha, because higher (500 x $10^{3}$ plants/ha) and medium plant density (333 $\times 10^{3}$ plants/ha) outyielded the lower plant density. The maximum pod yield was recorded with the highest plant density (24.5 t/ha) and the lowest pod yield with the lowest plant density (20.0 t/ha). These results are in agreement with the findings of Mozumder et al. (2003) and Singh et al. (1996). 


\section{Effects of nitrogen}

Plant height and branches per plant increased with increasing level of $\mathrm{N}$ (Table 1). Pod length, pod width, number of green pods per plant and green pod weight per plant were found highest at $120 \mathrm{~kg} \mathrm{~N} / \mathrm{ha}$. Higher values of plant height and number of branches per plant with $120 \mathrm{~kg} \mathrm{~N} / \mathrm{ha}$ resulted in better growth and development of plants, thus leading to the maximum pod size (pod length $\mathrm{x}$ width), more number of green pods per plant and green pod weight per plant. The result is in consonance with the findings of Dahatonde and Nalamwar (1996) and Dhanjal et al. (2001). The maximum pod yield (27.8 t/ha) was obtained from the application of $120 \mathrm{~kg} \mathrm{~N} / \mathrm{ha}$ and it was minimum (15.9 tha) in control (No) treatment. Higher yield for $120 \mathrm{~kg} N /$ ha fertilization was contributed by higher values for yield attributes compared to the lower dose (60 kg N/ha). These results are in agreement with the findings of Srinivas and Naik (1990) who recorded the maximum pod yield of French bean at $160 \mathrm{~kg}$ N/ha that was at par with $120 \mathrm{~kg}$ N/ha.

Tables 2. Yield attributes and yield of French bean as influenced by variety $x$ plant density and variety $\mathbf{x}$ nitrogen levels (average of two years).

\begin{tabular}{|c|c|c|c|c|c|c|c|c|}
\hline Treatments & $\begin{array}{l}\text { Plant } \\
\text { height } \\
(\mathrm{cm})\end{array}$ & $\begin{array}{c}\text { Number } \\
\text { of } \\
\text { branches/ } \\
\text { plant }\end{array}$ & $\begin{array}{c}\text { Plants } / \mathrm{m}^{2} \\
\text { (no.) }\end{array}$ & $\begin{array}{l}\text { Pod } \\
\text { length } \\
(\mathrm{cm})\end{array}$ & $\begin{array}{c}\text { Pod } \\
\text { width } \\
(\mathrm{cm})\end{array}$ & $\begin{array}{c}\text { Number } \\
\text { of green } \\
\text { fruits/ } \\
\text { plant }\end{array}$ & $\begin{array}{c}\text { Green } \\
\text { pod } \\
\text { wt / } \\
\text { plant (g) }\end{array}$ & $\begin{array}{l}\text { Green } \\
\text { pod } \\
\text { yield } \\
\text { (t/ha) }\end{array}$ \\
\hline \multicolumn{9}{|c|}{ Variety $x$ plant density } \\
\hline $\mathrm{V}_{1} \mathrm{~S}_{1}$ & 45.lab & 3.65 & $44.0 \mathrm{a}$ & 11.8 & 0.70 & 18.lbc & $62.0 \mathrm{e}$ & $26.1 \mathrm{a}$ \\
\hline $\mathrm{V}_{1} \mathrm{~S}_{2}$ & 44.9ab & 4.11 & $29.6 c$ & 12.3 & 0.72 & $19.8 b$ & $80.3 c$ & $22.8 b$ \\
\hline $\mathrm{V}_{1} \mathrm{~S}_{3}$ & $46.0 \mathrm{a}$ & 4.29 & $22.6 \mathrm{~d}$ & 12.8 & 0.72 & $23.6 \mathrm{a}$ & $99.0 \mathrm{a}$ & 21.lc \\
\hline $\mathrm{V}_{2} \mathrm{~S}_{1}$ & $43.9 b$ & 4.06 & $44.9 \mathrm{a}$ & 11.6 & 0.64 & $17.4 \mathrm{e}$ & $55.6 f$ & $3.4 \mathrm{~b}$ \\
\hline $\mathrm{V}_{2} \mathrm{~S}_{2}$ & $41.3 \mathrm{c}$ & 4.46 & $30.0 \mathrm{c}$ & 12.3 & 0.68 & $19.9 b$ & $74.7 d$ & $22.5 b$ \\
\hline $\mathrm{V}_{2} \mathrm{~S}_{3}$ & 40.Oc & 4.58 & $22.5 \mathrm{~d}$ & 12.5 & 0.69 & 23.la & 84.lb & $18.8 \mathrm{~d}$ \\
\hline \multicolumn{9}{|c|}{ Variety $x$ nitrogen } \\
\hline $\mathrm{V}_{1} \mathrm{~N}_{0}$ & $40.8 \mathrm{~d}$ & 3.76 & 31.8 & 12.0 & 0.70 & $16.0 \mathrm{c}$ & $57.0 \mathrm{~d}$ & $15.86 f$ \\
\hline $\mathrm{V}_{1} \mathrm{~N}_{1}$ & $46.4 \mathrm{~b}$ & 4.02 & 31.8 & 12.5 & 0.71 & $20.9 b$ & $86.9 \mathrm{~b}$ & $24.3 c$ \\
\hline $\mathrm{V}_{1} \mathrm{~N}_{2}$ & 48.Sa & 4.27 & 32.1 & 12.5 & 0.74 & $21.5 b$ & $96.5 \mathrm{a}$ & $30.0 \mathrm{a}$ \\
\hline $\mathrm{V}_{2} \mathrm{~N}_{9}$ & $38.8 \mathrm{e}$ & 3.95 & 32.7 & 11.9 & 0.64 & 15.lc & $51.2 \mathrm{e}$ & 16.le \\
\hline $\mathrm{V}_{2} \mathrm{~N}_{1}$ & $41.8 \mathrm{~d}$ & 4.36 & 31.9 & 12.3 & 0.67 & $21.4 \mathrm{~b}$ & $77.4 \mathrm{c}$ & 22.3d \\
\hline $\mathrm{V}_{2} \mathrm{~N}_{2}$ & $44.6 \mathrm{c}$ & 4.79 & 32.0 & 12.4 & 0.70 & $23.8 \mathrm{a}$ & $85.8 \mathrm{~b}$ & $25.7 \mathrm{~b}$ \\
\hline CV(\%) & 3.48 & 6.58 & 3.85 & 4.90 & 2.86 & 5.01 & 6.15 & 5.81 \\
\hline
\end{tabular}

Figures having uncommon letters in a column are significantly different at 5\% level of probability by DMRT

$\mathrm{S}_{1}=500 \times 10^{3}, \mathrm{~S}_{2}=333 \times 10^{3}, \mathrm{~S}_{3}=250 \times 10^{3}$ plants $/$ ha

$\mathrm{N}_{0}=0, \mathrm{~N}_{1}=60$ and $\mathrm{N}_{2}=120 \mathrm{~kg} \mathrm{~N} / \mathrm{ha} ; \mathrm{V}_{1}=$ BARI bush bean-I, $\mathrm{V}_{2}=$ BARI bush bean-2 


\section{Combined effect of variety and plant density}

Plant height, number of green pods, green pod weight per plant as well as green pod yield per hectare was significantly influenced by variety $\mathrm{x}$ plant density (Table 2). The maximum plant height was obtained with $\mathrm{V}_{1} \mathrm{~S}_{3}$, which is statistically at par with $\mathrm{V}_{1} \mathrm{~S}_{1}$ and $\mathrm{V}_{1} \mathrm{~S}_{2}$. The treatment $\mathrm{V}_{1} \mathrm{~S}_{3}$ gave the maximum number of green pods per plant that was statistically similar to $V_{2} S_{3}$ treatment. The highest green pod weight per plant was obtained from $V_{1} S_{3}$ treatment (99.0 g) followed by $\mathrm{V}_{2} \mathrm{~S}_{3}$ treatment (84.2 g). However, the treatment combination of $\mathrm{V}_{1} \mathrm{~S}_{1}$ gave the highest pod yield (26.1 t/ha). This is in perfect agreement with the results of Anon. (2000 a) that BARI bush bean-I gave the maximum pod yield at $20 \mathrm{~cm} \times 10 \mathrm{~cm}$ spacing.

\section{Combined effect of variety and nitrogen}

Plant height, number of green pods per plant, green pod weight per plant and green pod yield per hectare were significantly influenced by variety x nitrogen (Table 2). The maximum plant height $(48.8 \mathrm{~cm})$ was obtained from $V_{1} N_{2}$ treatment combination whereas, the highest number of green pods per plant was found from $\mathrm{V}_{2} \mathrm{~N}_{2}$ treatment. The treatment $\mathrm{V}_{1} \mathrm{~N}_{2}$ produced the highest green pod weight per plant $(96.5 \mathrm{~g})$ and green pod yield (30.0 t/ha). The results are in close conformity with the findings of Anon. (2000b) that the pod yield of BARI bush bean-I increased with the increase of urea-N. Anon (2000c) reported that the highest pod yield of BARI bush bean -2 was obtained at $75 \mathrm{~kg} \mathrm{~N} / \mathrm{ha}$.

\section{Combined effect of plant density and nitrogen}

The data in Table 3 indicate that there was significant differences in plant height, number of green pods and green pod weight per plant and green pod yield due to plant density $\mathrm{x}$ nitrogen rate interaction. The maximum plant height in BARI bush bean-I $\left(\mathrm{V}_{1}\right)$ was recorded with the highest plant density $\left(\mathrm{S}_{1}\right)$ at $120 \mathrm{~kg} \mathrm{~N} / \mathrm{ha}$ $\left(\mathrm{N}_{2}\right)$, whereas BARI bush bean-2 $\left(\mathrm{V}_{2}\right)$ had similar response to $\mathrm{S}_{3} \mathrm{~N}_{2}, \mathrm{~S}_{1} \mathrm{~N}_{1}, \mathrm{~S}_{1} \mathrm{~N}_{2}$ and $\mathrm{S}_{2} \mathrm{~N}_{2}$, while the minimum plant height was recorded at $\mathrm{S}_{3} \mathrm{~N}_{0}$ for both varieties. Average data of two varieties indicate that $S_{1} N_{2}$ treatment gave the maximum plant height closely followed by $\mathrm{S}_{3} \mathrm{~N}_{2}$. Anon. (2000b) reported that the close spacing of $20 \mathrm{~cm} \times 10 \mathrm{~cm}$ coupled with the highest $\mathrm{N}$ produced maximum plant height. The maximum number of green pods per plant and green pod weight per plant was recorded with the lower plant density at the highest nitrogen level $\left(\mathrm{S}_{3} \mathrm{~N}_{2}\right)$ in both the varieties whereas, the highest plant density with $0 \mathrm{~kg}$ $\mathrm{N} /$ ha $\left(\mathrm{S}_{1} \mathrm{~N}_{0}\right)$ gave the lowest values. The maximum pod yield per ha was recorded with the highest plant density at the highest dose of $N(120 \mathrm{~kg} / \mathrm{ha})$ in both the varieties, while minimum pod yield per hectare was noticed in control $\mathrm{N}$ with the highest plant density $\left(\mathrm{S}_{1} \mathrm{~N}_{0}\right)$. Average performance of two varieties indicate that 
the highest plant density accompanied by the highest $\mathrm{N}$ levels $\left(\mathrm{S}_{1} \mathrm{~N}_{2}\right)$ gave the highest pod yield per ha.

Table 3. Yield attributes and yield of French bean as influenced by plant density $x$ nitrogen levels (average of 2 years).

\begin{tabular}{|c|c|c|c|c|c|c|c|c|c|}
\hline \multirow{2}{*}{$\begin{array}{l}\text { Spacing } x \\
\text { Nitrogen }\end{array}$} & \multicolumn{3}{|c|}{ Plant height (cm) } & \multicolumn{3}{|c|}{ Pod length $(\mathrm{cm})$} & \multicolumn{3}{|c|}{ Pod width (cm) } \\
\hline & $\mathrm{V}_{1}$ & $\mathrm{~V}_{2}$ & Mean & $V_{1}$ & $V_{2}$ & Mean & $\mathrm{V}_{1}$ & $V_{2}$ & Mean \\
\hline $\mathrm{S}_{1} \mathrm{~N}_{0}$ & $36.8 \mathrm{e}$ & $33.7 \mathrm{~d}$ & $36 . .3 f$ & 11.7 & 11.3 & 11.5 & 0.70 & 0.61 & 0.65 \\
\hline $\mathrm{S}_{1} \mathrm{~N}_{1}$ & $46.4 \mathrm{c}$ & $44.7 \mathrm{a}$ & $45.5 \mathrm{~b}$ & 12.1 & 11.9 & 12.0 & 0.70 & 0.64 & 0.67 \\
\hline${ }_{1} \mathrm{~N}_{2}$ & 53.3a & 44.3a & $48.8 \mathrm{a}$ & 12.1 & 12.2 & 12.1 & 0.72 & 0.66 & 0.69 \\
\hline $\mathrm{S}_{2} \mathrm{~N}_{0}$ & $42.3 \mathrm{~d}$ & 38.9c & 40.ld & 11.9 & 12.4 & 12.1 & 0.70 & 0.64 & 0.67 \\
\hline $\mathrm{S}_{2} \mathrm{~N}_{1}$ & $45.8 \mathrm{c}$ & $40.8 \mathrm{~b}$ & $43.3 \mathrm{c}$ & 12.7 & 12.7 & 12.7 & 0.73 & 0.67 & 0.70 \\
\hline $\mathrm{S}_{2} \mathrm{~N}_{2}$ & $46.6 \mathrm{e}$ & $44.2 \mathrm{a}$ & $5.4 \mathrm{~b}$ & 12.5 & 12.3 & 12.4 & 0.73 & 0.71 & 0.72 \\
\hline $\mathrm{S}_{1} \mathrm{~N}_{0}$ & $41.5 \mathrm{~d}$ & $34.8 \mathrm{~d}$ & 38.le & 12.1 & 12.3 & 12.2 & 0.72 & 0.63 & 0.67 \\
\hline $\mathrm{S}_{3} \mathrm{~N}_{1}$ & $48.2 \mathrm{~b}$ & $40.0 \mathrm{~b}$ & 44.lc & 12.6 & 12.8 & 12.6 & 0.72 & 0.69 & 0.70 \\
\hline $\mathrm{S}_{3} \mathrm{~N}_{2}$ & 49.lb & $45.4 \mathrm{a}$ & 47.3a & 13.4 & 13.4 & 13.40 & 0.73 & 0.71 & 0.72 \\
\hline CV (\%) & & 3.48 & & & 4.90 & & & 2.86 & \\
\hline
\end{tabular}

Table 3. Cont'd.

\begin{tabular}{l|l|l|l}
\hline Spacing $\mathrm{x}$ & No. of green pods/plant & Green pod weight/plant (g) & Green pod yield (t/ha) \\
\hline
\end{tabular}

\begin{tabular}{|c|c|c|c|c|c|c|c|c|c|}
\hline Nitrogen & $\mathrm{V}_{1}$ & $\mathrm{~V}_{2}$ & Mean & $\mathrm{V}_{1}$ & $\mathrm{~V}_{2}$ & Mean & $V_{1}$ & $V_{2}$ & Mean \\
\hline
\end{tabular}

\begin{tabular}{llllllllll}
\hline $\mathrm{S}_{1} \mathrm{~N}_{0}$ & $13.5 \mathrm{f}$ & $13.7 \mathrm{e}$ & $13.6 \mathrm{f}$ & $46.3 \mathrm{~h}$ & $40.9 \mathrm{~g}$ & $43.6 \mathrm{~g}$ & $15.6 \mathrm{e}$ & $14.3 \mathrm{f}$ & $14.9 \mathrm{f}$
\end{tabular}

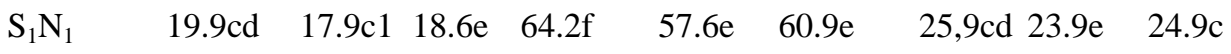

$\begin{array}{llllllllll}\mathrm{S}_{1} \mathrm{~N}_{2} & 20.6 \mathrm{c} & 20.5 \mathrm{c} & 20.5 \mathrm{~d} & 75.4 \mathrm{e} & 68.4 \mathrm{~d} & 71.9 \mathrm{~d} & 34.3 \mathrm{a} & 30.2 \mathrm{a} & 32.2 \mathrm{a}\end{array}$

$\begin{array}{llllllllll}\mathrm{S}_{2} \mathrm{~N}_{0} & 15.7 \mathrm{e} & 13.9 \mathrm{e} & 14.8 \mathrm{f} & 55.7 \mathrm{~g} & 52.8 \mathrm{f} & 54.3 \mathrm{f} & 16.6 \mathrm{e} & 19.2 \mathrm{e} & 17.9 \mathrm{e}\end{array}$



$\begin{array}{lllllllll}\mathrm{S}_{2} \mathrm{~N}_{2} & 22.8 \mathrm{~b} & 23.2 \mathrm{~b} & \text { 23.0bc 95.lc } & \text { 86.8c } & 91.4 \mathrm{c} & 28.8 \mathrm{~b} & 26.9 \mathrm{~b} & 27.6 \mathrm{~b}\end{array}$

$\begin{array}{llllllllll}\mathrm{S}_{3} \mathrm{~N}_{0} & 18.9 \mathrm{~d} & 17.8 \mathrm{~d} & 18.3 \mathrm{e} & 71.7 \mathrm{e} & 60.1 \mathrm{e} & 65.8 \mathrm{de} & 15.7 \mathrm{e} & 14.7 \mathrm{f} & 15.2 \mathrm{f}\end{array}$

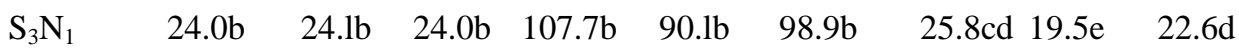

\begin{tabular}{|c|c|c|c|c|c|}
\hline & $27.8 \mathrm{a}$ & 27.8 & $27.8 \mathrm{a}$ & $7.7 \mathrm{a}$ & 1023 \\
\hline
\end{tabular}

$\begin{array}{llll}\mathrm{CV}(\%) & 3.48 & 6.15 & 5.81\end{array}$

Figures having uncommon letters in a column are significantly different at $5 \%$ level of probability by DMRT

$\mathrm{S}_{1}=500 \times 10_{3}, \mathrm{~S}_{2}=333 \times 10_{3}, \mathrm{~S}_{3}=250 \times 10_{3}$ plants/ha

$\mathrm{N}_{0}=0, \mathrm{~N}_{1}=60$ and $\mathrm{N}_{2}=120 \mathrm{~kg} \mathrm{~N} / \mathrm{ha} ; \mathrm{V}_{1}=$ BARI Bush bean- $1, \mathrm{~V}_{2}=$ BARI Bush bean-2

From the above discussion, it could be concluded that French bean (BARI bush bean-I and BARI bush bean-2) should be cultivated at the plant density of $500 \times 10^{3}$ plants per ha $(20 \times 10 \mathrm{~cm})$ with application of $120 \mathrm{~kg} \mathrm{~N} / \mathrm{ha}$ for obtaining higher yield in Rangamati area. 


\section{References}

All, M. 1998. Response of french bean genotypes to population density during winter season. Indian J. Pulse Res. 2 (2): 125-128.

Anonymous. 2000a. Research Report on horticultural crops for 1999-2000. Agril Res. Station, Raikhali, Rangamati. pp. 1-2.

Anonymous. 2000b. Research Report on Vegetable Improvement for 1999-2000. Olericulture Division, HRC, BARI, Joydebpur, Gazipur. pp 38-39.

Anonymous. 2000c. Annual Report for 1999-2000. Bangladesh Agricultural Research Institute (BARI), Joydebpur, Gazipur. p. 308.

Dahatonde, B. N. and R. V. Nalamwar. 1996. Effect of nitrogen and irrigation levels on yield and water use of French bean (Phaseolus vulgaris L.). Indian J. Agron. 41(2): 265-268.

Dhanjal, R., 0. Prakash and I. P. S. Ahlawat. 2001. Response of French bean (Phaseolus vulgaris L.) varieties to plant density and nitrogen application. Indian J. Agron. 46(2): 277-281.

Mozumder, S. N., M. Moniruzzaman, M. R. Islam and S. N. Alam. 2003. Effect of planting time and spacing on the yield performance of bush bean (Phaseolus vulgaris L.) in the eastern hilly area of Bangladesh. Leg. Res., India. 26 (4): 242-247.

Rana, N. S., R. Singh and I. P. S. Ahlawat. 1998. Dry matter production and nutrient uptake in French bean (Phaseolus vulgaris L.)) as affected by nitrogen and phosphorous application. Indian J. Agron. 43 (1): 114-117.

Shivakumar, B. G., C. S. Saraf and R. R. Path. 1996. Performance of winter French bean as influenced by varieties, spacing and time of sowing. Ann. Agrie Res. 17 (4): 407-410.

Singh, D. P., A. L. Rajat and S. K. Singh. 1996. Response of french bean (Phaseolus vulgaris L.) to spacing and nitrogen levels. Indian J. Agron. 41(4): 608-610.

Srinivas, K. and L. B. Naik. 1990. Growth, yield and nitrogen uptake in vegetable French bean (Phaseolus vulgaris L.) as influenced by nitrogen and phosphorous fertilization. Haryana J. Hort. Sci. 19 (1-2): 160-167. 